\title{
Ice stream or not? Radio-echo sounding of Carlson Inlet, West Antarctica
}

\author{
E. C. King \\ British Antarctic Survey, Madingley Road, Cambridge, CB3 0ET, UK \\ Received: 1 April 2011 - Published in The Cryosphere Discuss.: 20 April 2011 \\ Revised: 30 September 2011 - Accepted: 11 October 2011 - Published: 21 October 2011
}

\begin{abstract}
The Antarctic Ice Sheet loses mass to the surrounding ocean mainly by drainage through a network of ice streams: fast-flowing glaciers bounded on either side by ice flowing one or two orders of magnitude more slowly. Ice streams flow despite low driving stress because of low basal resistance but are known to cease flowing if the basal conditions change, which can take place when subglacial sediment becomes dewatered by freezing or by a change in hydraulic pathways. Carlson Inlet, Antarctica has been interpreted as a stagnated ice stream, based on surface and basal morphology and shallow radar reflection profiling. To resolve the question of whether the flow history of Carlson Inlet has changed in the past, I conducted a ground-based radar survey of Carlson Inlet, the adjacent part of Rutford Ice Stream, and Talutis Inlet, West Antarctica. This survey provides details of the internal ice stratigraphy and allows the flow history to be interpreted. Tight folding of isochrones in Rutford Ice Stream and Talutis Inlet is interpreted to be the result of lateral compression during convergent flow from a wide catchment into a narrow, fast-flowing trunk. In contrast, the central part of Carlson Inlet has gently-folded isochrones that drape over the bed topography, suggestive of local accumulation and slow flow. A 1-D thermo-mechanical model was used to estimate the age of the ice. I conclude that the ice in the centre of Carlson Inlet has been near-stagnant for between 3500 and $6800 \mathrm{yr}$ and that fast flow has not occurred there during that time period.
\end{abstract}

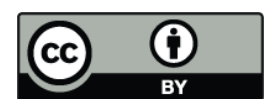

Correspondence to: E. C. King (ecki@bas.ac.uk)

\section{Introduction}

Ice streams form the main drainage system for ice sheets. It is therefore important to understand the history of icestream flow in the past in order to constrain modelling of ice sheet behaviour during future climate change. Ice stream flow is now known to be capable of significant variation over short timescales. One example was documented from the ice streams flowing into the Ross Ice Shelf. Kamb Ice Stream (formerly known as Ice Stream C) ceased fast flow about $150 \mathrm{yr}$ ago (Retzlaff and Bentley, 1993) and the main trunk is now stagnant. This ice stream is thought to have thinned to the point where basal melting changed to basal freezing which removed water from the basal till causing stiffening of the substrate, a decrease in lubrication and eventual stoppage (Tulaczyk et al., 2000a, b; Bougamont et al., 2003; Christoffersen and Tulaczyk, 2003; Hulbe and Fahnestock, 2004; Catania et al., 2006).

It has been argued that one of the ice streams flowing into the Ronne Ice Shelf may also have shut down. Vaughan et al. (2008) suggested that Carlson Inlet is a relict ice stream that ceased streaming more than $240 \mathrm{yr}$ ago, but sufficiently recently that the surface morphology, basal water content and basal morphology retain characteristics produced by fast flow. An analysis of the current surface morphology suggested that Carlson Inlet is not presently streaming because subglacial water is preferentially directed beneath Rutford Ice Stream.

Fast-flowing ice streams have a distinctive internal structure as revealed by ice-penetrating radar. On profiles across the flow direction the isochrones are frequently folded with a wavelength of $1-2 \mathrm{~km}$, probably as a result of lateral compression as tributaries converge into the main trunk or due to accelerating flow over bedrock topography (Jacobel et al., 1993; Ng and Conway, 2004; Robin and Millar, 1982;

Published by Copernicus Publications on behalf of the European Geosciences Union. 
Siegert et al., 2003). This contrasts with slow-flowing intraice stream areas where radargrams usually show gently undulating isochrones and where any structure tends to conform to the basal topography (Jacobel and Welch, 2005; Siegert et al., 2003). Thus radar profiles can provide a diagnostic tool for identifying regions of past and present fast flow.

In this paper, I demonstrate that the majority of Carlson Inlet has an internal radar stratigraphy of open, draped folds, while Rutford Ice Stream and Talutis Inlet, which both abut Carlson Inlet, have internal stratigraphy characterised by tight folds indicative of a history of lateral compression. I use a 1-D thermo-mechanical model to provide an estimate of the age of the ice in the area and show that flow switching between Carlson Inlet and Rutford Ice Stream has not taken place during much of the Holocene.

\section{Location and previous work}

Carlson Inlet (Fig. 1a) is a relatively short feature, $83 \mathrm{~km}$ from the grounding line to the shallow ice divide that separates it from Rutford Ice Stream. The catchment area is approximately $3250 \mathrm{~km}^{-2}$ (note that this figure is less than that in Joughin and Bamber (2005) because I subdivide the area those authors label Carlson, into Carlson and Talutis sectors). It has a width of $30 \mathrm{~km}$ similar to that of the adjacent part of Rutford Ice Stream but has a much lower flow rate of between 5 and $35 \mathrm{~m} \mathrm{a}^{-1}$ (Frolich et al., 1989; Vaughan et al., 2008). Like Rutford Ice Stream, Carlson Inlet lies in a deep, linear trough (Fig. 1b) (Doake et al., 1987). The ice in Carlson Inlet is between 1700 and 2000 m thick with the deepest parts adjacent to Kealey Ice Rise. Carlson Inlet and Rutford Ice Stream have similar width, surface slope, driving stress and ice thickness (Vaughan et al., 2008). The significant differences are the length and the flow rate. Vaughan et al. (2008) argued that the morphology and basal conditions suggested that Carlson Inlet was once fast flowing. They further showed that redirection of basal water into Carlson Inlet should take place if the surface elevation of Rutford Ice Stream was $120 \mathrm{~m}$ higher than at present and concluded that it was feasible that ice flow may have diverted from Carlson Inlet into Rutford Ice Stream at some time in the past.

The fast-flowing trunk of Rutford Ice Stream flows SSE down the eastern side of the Ellsworth Mountains (Fig. 1). It drains a catchment of $47000 \mathrm{~km}^{2}$ (Joughin and Bamber, 2005) that lies mostly to the west and north of the mountains. Treating the approximate length of an ice stream as the along-flow distance between the onset of fast flow $\left(>100 \mathrm{~m} \mathrm{a}^{-1}\right)$ and the grounding line Rutford Ice Stream is $240 \mathrm{~km}$ long. The flow speed in the main trunk is 300 $400 \mathrm{~m} \mathrm{a}^{-1}$ (Doake et al., 1987; Frolich et al., 1989).

Talutis Inlet (Fig. 1) is a valley lying to the east of Carlson Inlet. A minor ice stream $15 \mathrm{~km}$ wide and $130 \mathrm{~km}$ long discharges ice through Talutis Inlet from a catchment that includes the east side of Kealey Ice Rise and the west side of
Fowler Peninsula. In this paper, I propose to use the informal term Talutis Ice Stream to describe this ice flow element. Talutis Ice Stream joins Carlson Inlet to the south of Kealey Ice Rise.

Previous work on Carlson Inlet includes two seismic surveys, one at the NW end where the flow is around $7 \mathrm{ma}^{-1}$ (Smith, 2000) and one towards the SE end where the flow is $36 \pm 22 \mathrm{~m} \mathrm{a}^{-1}$ (Vaughan et al., 2003). Both surveys found evidence for thawed sediment beneath the ice, interpreted as lodged till.

\section{Data acquisition and processing}

The radar data was collected using the British Antarctic Survey's DELORES radar (Deep Look Radio Echo Sounder) (King et al., 2008). This is a monopulse radar operating in the $1-4 \mathrm{MHz}$ range that is based on designs developed by the University of Washington (Gades, 1998) and St Olaf College (Welch and Jacobel, 2003). The transmitter uses a $\pm 2 \mathrm{kV}$ pulser that has a variable firing rate between 1 and $5 \mathrm{kHz}$. The antennae are resistively-loaded wire dipoles and the receiver uses a chassis computer with a $100 \mathrm{MHz}$ digitising card. Between one and three thousand radar shots were stacked to produce each final trace on the radargram. The system was towed behind a skidoo at around $15 \mathrm{~km} \mathrm{~h}^{-1}$. The spatial interval between traces was 5 to $10 \mathrm{~m}$. The data were processed using the ReflexW software in the following sequence: edit; background removal (dewow, subtract average trace); bandpass filter, spherical spreading compensation, finite-difference migration, and topographic correction. Primary navigation of the surveys was done with hand-held GPS units and final positions determined using post-processed dual-frequency GPS data. Depth scales on the radargrams are based on a uniform radar wave speed of $0.168 \mathrm{~m} \mathrm{~ns}^{-1}$ and no firn correction has been applied. Horizontal banding on some of the radargrams near the bed is a processing artefact and some of the sections show a subtle, low-frequency banding between 6000 and $10000 \mathrm{~ns}$ which is an artefact of temperature changes in the system during acquisition.

\section{Data description}

The locations of the radargrams used in this study are shown in Fig. 1. The lines were selected from larger networks to illustrate the typical internal structure of the three flow elements under discussion, Rutford Ice Stream, Carlson Inlet and Talutis Ice Stream.

Line J300/J2925 (Fig. 2a) crossed the width of Rutford Ice Stream at a location where the flow speed is approximately $250 \mathrm{~m} \mathrm{a}^{-1}$. The line then passes between crevasses at the margin of the fast flow and onto slow-moving ice at the head of Carlson Inlet. The isochrones on each side of the Rutford flow margin have very different structures. Within Rutford Ice Stream the isochrones are folded with a wavelength of 

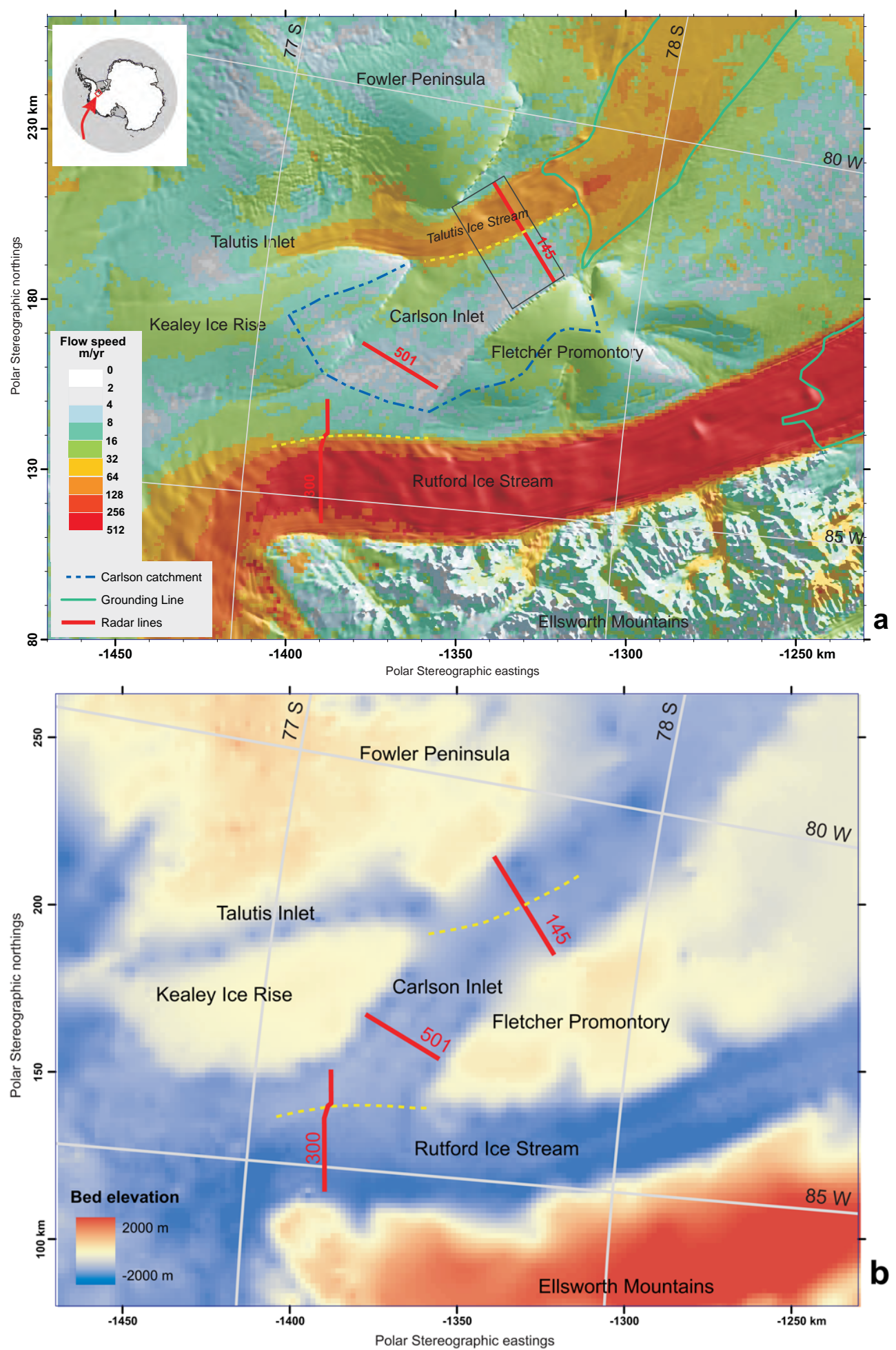

Fig. 1. Location map. (a) Background is a MODIS Mosaic of Antarctica (MOA) image (Haran et al., 2005: http://nsidc.org/data/moa), overprinted with flow velocities from inSAR analysis (Joughin and Bamber, 2005). Yellow dashed lines mark shear margins between fast flow in Rutford Ice Stream or Talutis Ice Stream (the fast-flow region originating in Talutis Inlet) and Carlson Inlet. Black rectangle marks outline of 3-D grid survey. Blue dash-dot line marks catchment boundary for Carlson Inlet. Polar Stereographic projection, grid is in metres from the origin. Geographic grid is in light grey. (b) Basal topography for the same area. Carlson Inlet and Rutford Ice Stream each occupy parallel-sided troughs about $30 \mathrm{~km}$ wide. 

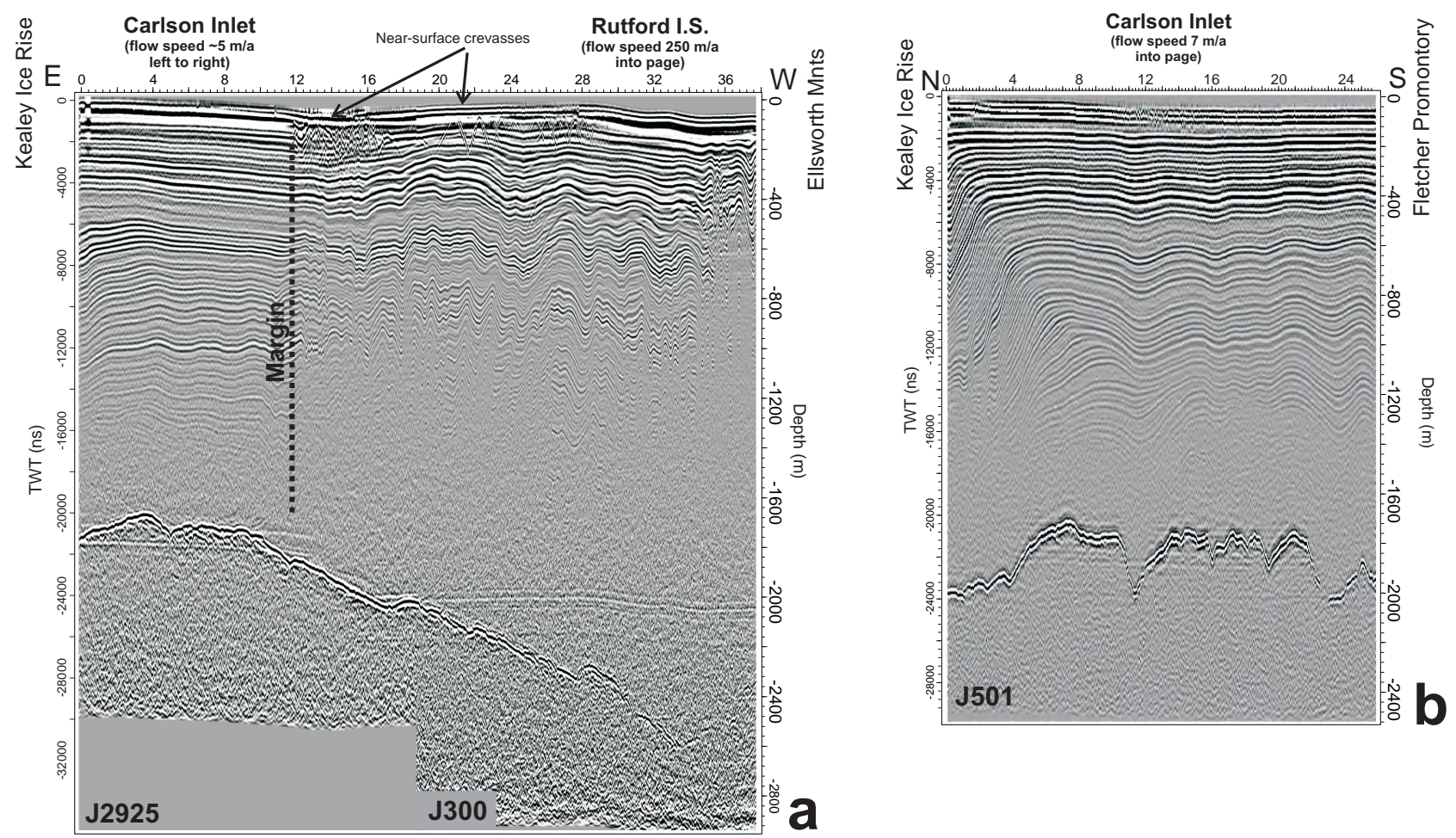

Fig. 2. Topographically-corrected radargrams across Rutford Ice Stream and the upstream part of Carlson Inlet. Locations in Fig. 1, horizontal scales are in kilometres, depth scales are based on a uniform radar wave speed of $0.168 \mathrm{~m} \mathrm{~ns}^{-1}$. Horizontal banding is a processing artefact. (a) Profile crossing the shear margin between Rutford Ice Stream and Carlson Inlet, flow direction is into the page for Rutford Ice Stream but is left to right for the Carlson Inlet section. Wavelength and amplitude of folding of isochrones changes beneath the outer edge of a band of near-surface crevasses that marks the shear margin. Folding in Rutford Ice Stream is very similar to the "fast-flow signature" described from Kamb Ice Stream by Ng and Conway (2004), here interpreted as the signature of convergent flow within the broad catchment upstream. (b) Profile crossing Carlson Inlet between Fletcher Promontory and Kealey Ice Rise, flow direction is into the page. Isochrone folds have long wavelengths, small amplitudes and conform to the basal topography except for a narrow zone within $3 \mathrm{~km}$ of the margin with Kealey Ice Rise.

1-2 km and amplitudes of up to $100 \mathrm{~m}$ whereas on the Carlson Inlet side, the folds are 3-4 km across and less than $40 \mathrm{~m}$ in amplitude. The transition between the two fold regimes lies directly beneath the outer edge of the marginal crevassing which is marked on the radargram by a zone of complex diffractions in the near-surface.

Line J501 (Fig. 2b) crosses the width of Carlson Inlet between Fletcher Promontory and Kealey Ice Rise (Fig. 1). The majority of this radargram shows isochrones with long wavelengths and low amplitudes which drape over the basal topography and are very similar in character to those at the eastern end of Line J2925 (Fig. 2a). The exception is a narrow zone about $3 \mathrm{~km}$ wide adjacent to Kealey Ice Rise which shows some shorter-wavelength folding between 10000 and $16000 \mathrm{~ns}$.

Line 145 (Fig. 3) crosses the downstream end of Carlson Inlet between Fletcher Promontory and Fowler Peninsula (Fig. 1). It crosses both the flow margin between Carlson Inlet and Talutis Ice Stream and the Talutis/Fowler margin. In the central portion of Carlson Inlet the isochrones are gener- ally smooth and fold amplitudes increase gradually toward the bed, where they drape over the topography. Between kms 25 and 29 the isochrones in the lower part of the section are tightly folded and between $\mathrm{km} 29$ and the Fletcher Promontory end of the profile, the reflectors become chaotic. Between km 25 at $900 \mathrm{~m}$ depth and $\mathrm{km} 29$ at $500 \mathrm{~m}$ depth there is a "hinge line" in the isochrones where dips increase markedly toward the SE. This is very similar to the North end of line J501 where a another hinge line is evident from $\mathrm{km} 0$ at $200 \mathrm{~m}$ depth and $\mathrm{km} 6$ at $800 \mathrm{~m}$ depth. The section from $\mathrm{km} 12$ to 17 also has shorter-wavelength isochrones with some similarity to the marginal zone of line J2925 (km 1014) (Fig. 2a). In the Talutis Ice Stream part of the section, the isochrones are folded with wavelengths of 0.5 to $1 \mathrm{~km}$ and amplitudes of 20 to $40 \mathrm{~m}$. The most intense folding is in the marginal zones to either side, however the flow margin in the centre of the radargram, which separates the fast Talutis flow from the very slow Carlson flow (as determined by the inSAR data; yellow dashed line in Fig. 1a), does not display strong folding, just a subtle change in the wavelength of 


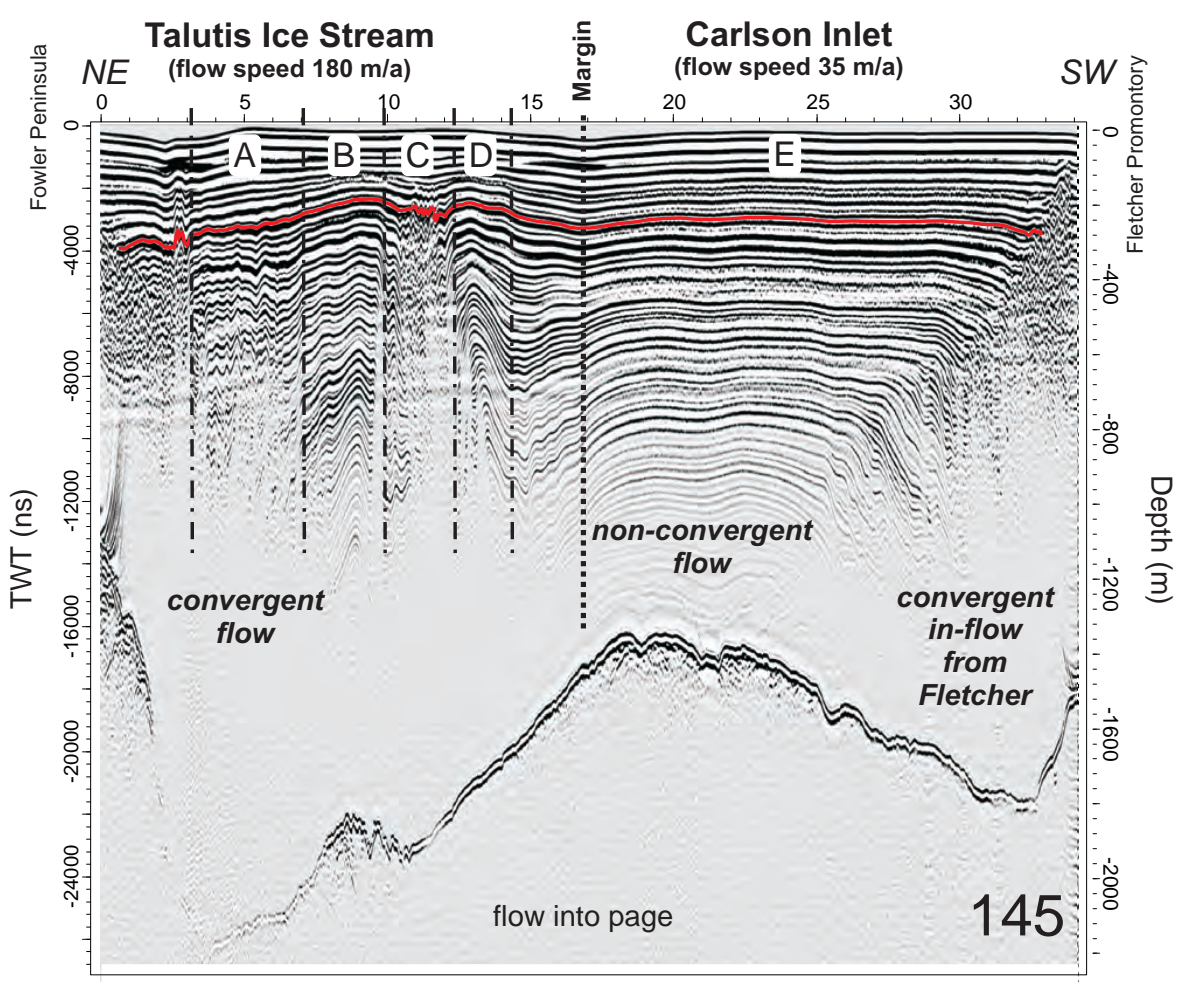

Fig. 3. Radargram across the downstream end of Carlson Inlet showing the contrast in isochrone structure between open, bed-conformable folds in the centre of Carlson Inlet and short-wavelength folds in Talutis Ice Stream. The shear margin between Talutis Ice Stream and Carlson Inlet (marked at the location of the surface flow speed change) is not crevassed despite a flow-speed differential of $145 \mathrm{ma}^{-1}$. Red line marks isochrone mapped in 3-D in Fig. 4a and the letters A to E mark zones of different styles of folding.

folds in the deeper part of the section. The red line in Fig. 3 marks an isochrone that was picked on the $35 \times 18 \mathrm{~km}$ grid of lines of which line 145 is a component. A 3-D view of the isochronal surface is shown in Fig. 4a, which shows the differences in isochrone morphology between the flow elements more clearly.

\section{Interpretation}

The short-wavelength folding observed in Rutford Ice Stream and Talutis Ice Stream is very similar to examples shown by Ng and Conway (2004) for the now stagnant Kamb Ice Stream. Enhanced flow in ice stream tributaries also results in folding, an example is the tributary feeding Bindschadler Ice Stream, $27 \mathrm{~km}$ SE of Byrd Station, shown in Jacobel and Welch (2005, Fig. 2). Debate continues as to the origin of such folding; convergence of ice from the tributary system into the main trunk; flow over basal topography in the onset region; and convergent flow over areas of basal melting are among the strongest candidate explanations (Leysinger Vieli et al., 2007; Robin and Millar, 1982; Siegert et al., 2003). It is clear from the configuration of the Rutford Ice Stream catchment (King, 2009) that lateral convergence must play a major role there. Talutis Ice Stream illus- trates a strong correlation between the degree of downstream convergence and the intensity of folding. Consider the zone of short-wavelength folds marked "A" in Fig. 4. Flow lines traced through this zone on the surface imagery (Fig. 1) converge in the downstream direction from a broad area of the western flank of Fowler Peninsula (Fig. 4b). The degree of horizontal shortening increases in successively deeper layers (Fig. 4c), suggesting that older ice that has travelled furthest has undergone a greater degree of lateral compression. On the other hand, zone "B", which is fast-flowing but less intensely folded, can be traced upstream along the centreline of Talutis Inlet with a relatively small change in width and there is no significant difference in horizontal shortening with depth for the same isochrones. Hence zones A and B have different histories of lateral compression. Therefore it is my interpretation that the short-wavelength folds in both Rutford Ice Stream and Talutis Ice Stream arise largely from lateral compression of the ice during convergent flow in the onset region.

In Carlson Inlet, the majority of the isochrones form long wavelength folds of low amplitude that are strongly correlated with the basal topography (Figs. $2 \mathrm{~b}$ and 3 ). However towards the margins of Carlson Inlet, especially the margin with Fletcher Promontory in Fig. 3, the isochrone folds have shorter wavelengths, similar to those interpreted 

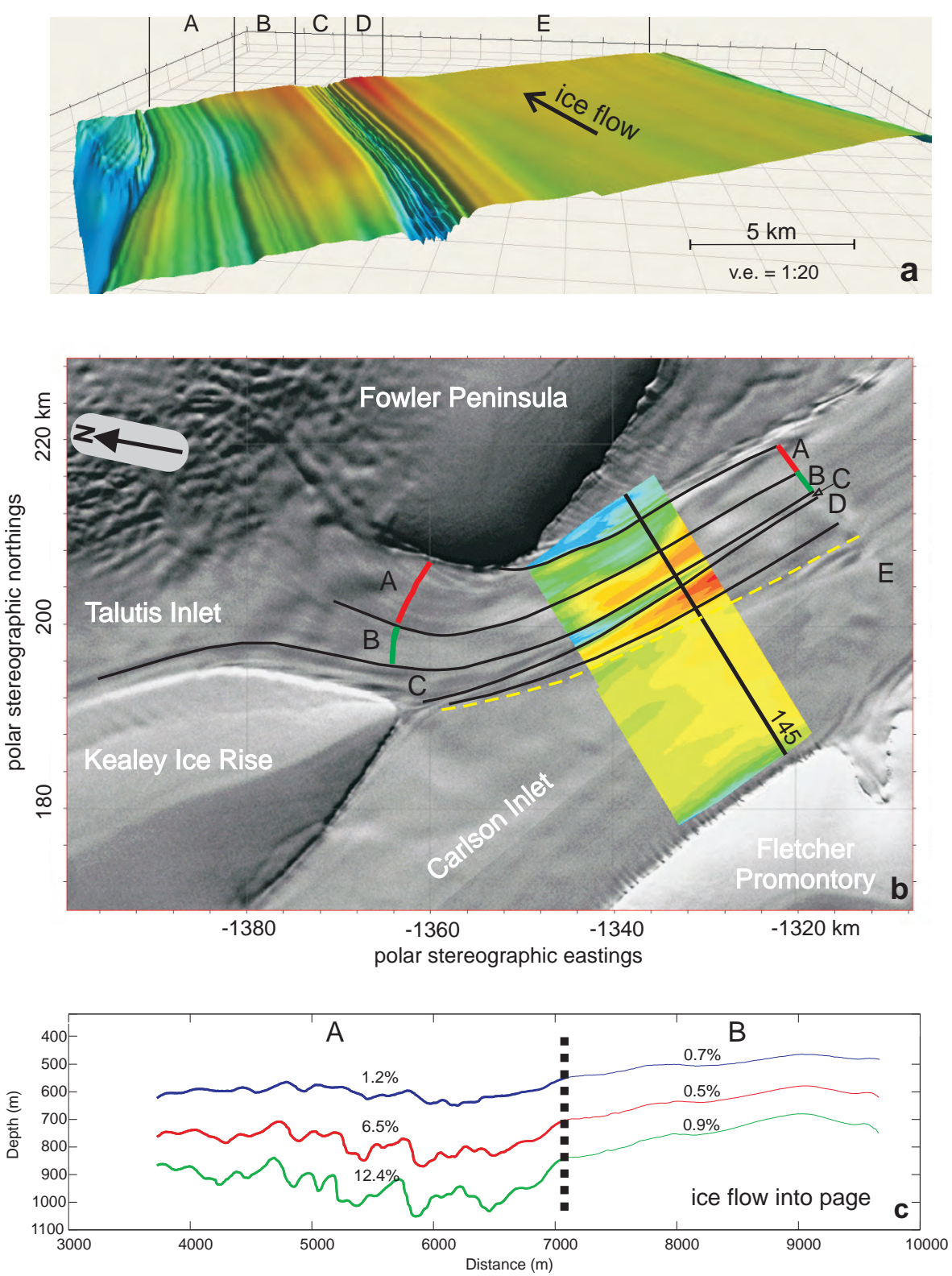

Fig. 4. (a) Three-dimensional view of one isochrone from a depth of approximately $200 \mathrm{~m}$ derived from interpretation of a grid of lines each spaced $500 \mathrm{~m}$ apart covering the box shown in Fig. 1. Ice flow is away from the observer and the vertical range of the surface is $60 \mathrm{~m}$. (b) Map view of the confluence of Talutis Ice Stream and Carlson Inlet with the $200 \mathrm{~m}$ isochrone shown as a colour contour plot superimposed on a MOA surface image. Zone A represents Talutis Ice Stream ice derived from the western flank of Fowler Peninsula that has experienced lateral compression during downstream flow. Zone B is ice that has flowed down the centre of Talutis Inlet with little lateral compression. Zone $\mathrm{C}$ is the shear margin generated as Talutis Ice Stream enters Carlson Inlet. Zone D is Carlson Inlet ice up warped by lateral compression from the inflow of Talutis Ice Stream into Carlson Inlet, this ice is entrained into the fast flow. Zone E is the region of Carlson Inlet that has undergone no lateral compression and is slow-flowing. (c) Line drawing of isochrones in zones A and B. Figures above each horizon indicate the percentage of horizontal shortening experienced by that section. Both zones A and B are fast flowing but zone A has undergone a higher degree of convergence compared to zone B.

as convergent folding in Talutis and Rutford Ice Streams. I interpret this folding to be due to compression from ice flowing off the adjacent ice rises. Figure $1 \mathrm{~b}$ shows that Carlson Inlet occupies a trough flanked by high ground beneath
Kealey Ice Rise and Fletcher Promontory. It is therefore likely that the present situation where the snow surface slopes relatively steeply towards Carlson Inlet from the ice rises has pertained for some time, indeed there is evidence from 
Kealey Ice Rise and Fletcher Promontory that the ice divides have been stable for around $5 \mathrm{kyr}$ (Martin et al., 2009). The resultant driving stress induces a component of lateral compression at the margins of Carlson Inlet which explains the enhanced folding seen in the isochrones.

One interesting contrast between Figs. $2 \mathrm{a}$ and 3 is in the nature of the margin between fast flow and slow flow. The margin between Rutford Ice Stream and Carlson Inlet has a speed differential of $>200 \mathrm{~m} \mathrm{a}^{-1}$ and is marked by a band of near-surface crevasses about $4 \mathrm{~km}$ wide but there is little to mark the margin in the deeper isochrones other than an abrupt change in the fold wavelength. In contrast, the Talutis Ice Stream/Carlson margin (dashed line, Fig. 3) is not crevassed at all, despite a speed differential of $>140 \mathrm{~m} \mathrm{a}^{-1}$. The narrow zone of very intense folding between $\mathrm{km} 10$ and $\mathrm{km} 12$ on line 145 (zone C, Fig. 3) can be traced upstream to the southern tip of Kealey Ice Rise (Fig. 1) and represents the intense shear that arises as Talutis Ice Stream enters Carlson Inlet.

The key question is whether there is any evidence in the radar stratigraphy of Carlson Inlet that supports the hypothesis that the fast flow which presently goes down the Rutford Ice Stream trough once also went down the Carlson trough, either as a complete switching of the flow or as a bifurcated flow. If it is true that the short-wavelength folding observed on line J300 (Fig. 2a) was developed in the onset region 50 or more kilometres upstream, then any fast-flowing ice traversing Carlson Inlet due to a different surface elevation profile as envisaged by Vaughan et al. (2008) should have carried that stratigraphic signature. Figures $2 \mathrm{~b}$ and 3 clearly show that the ice in Carlson Inlet does not have the convergentflow signature, there is only a signature of localised lateral compression in the margins due to in-flow from the adjacent ice rises.

It is therefore possible to say with a high level of confidence that there has not been any flow of ice that originated in the Rutford onset region in the period of time represented by the ice presently occupying Carlson Inlet. There is no direct measurement of the age of the ice in Carlson Inlet, so we now consider estimation of the age based on a modelling approach.

\section{Estimation of the age of ice in Carlson Inlet}

A 1-D thermo-mechanical model was used to estimate the age-depth profile for the ice in Carlson Inlet (Hindmarsh, 1999). The inputs to the model are ice thickness, accumulation rate, surface temperature and geothermal heat flux. Ice thickness is provided by the radar data and is taken as $1700 \mathrm{~m}$ (Fig. 2b). I adopt values of between $0.5 \mathrm{~m} \mathrm{a}^{-1}$ and $0.7 \mathrm{~m} \mathrm{a}^{-1}$ (Frolich et al., 1989) as a suitable range of accumulation for Carlson Inlet. I adopt $-26.5^{\circ} \mathrm{C}$ as the surface temperature (Barrett et al., 2009) and $0.08 \mathrm{~W} \mathrm{~m}^{-2}$ as the geothermal heat flux (Shapiro and Ritzwoller, 2004), which produces melting at the bed.

The result of the 1-D model is shown in Fig. 5. A suite of age-depth relations were computed, in two sets, one set assuming sliding over the bed (plug flow) and one set assuming internal deformation only (flow exponent $n=3$ ). The parameters were varied as follows to test the sensitivity: accumulation rate by $\pm 0.1 \mathrm{ma}^{-1}$; geothermal heat flux by $\pm 0.01 \mathrm{~W} \mathrm{~m}^{-2}$; surface temperature by $\pm 1.5^{\circ} \mathrm{C}$. The modelled age at $1300 \mathrm{~m}$ below surface (the depth of the lowermost continuous reflector on profile J501; Fig. 2b) was between 3500 and $6800 \mathrm{yr}$, the lower estimate was for plug flow and the higher for internal deformation.

The basal temperature suggested by the modelling is at the pressure melting point for the internal deformation case. This is consistent with seismic reflection surveys on Carlson Inlet that showed that the ice was underlain by unfrozen sediment (Smith, 2000; Vaughan et al., 2003). The interpretation of the seismic data was that the sediment beneath Carlson Inlet is lodged till. The survey by Smith (2000) was conducted $11 \mathrm{~km} \mathrm{WNW} \mathrm{of} \mathrm{radar} \mathrm{line} \mathrm{J501.} \mathrm{The} \mathrm{number} \mathrm{of}$ natural seismic events arising from the bed in this location was very low (Smith, 2000), suggesting that there was little basal sliding taking place, although plug flow at a slow rate is not excluded by this result. The small rate of surface flow $\left(7 \mathrm{~m} \mathrm{a}^{-1}\right)$ could be accounted for by internal deformation alone. On the presently available data, I cannot distinguish between plug flow and internal deformation, therefore I can only say that the lowermost continuous reflector on the radar data is between approximately 3500 and $6800 \mathrm{yr}$ old based on the 1-D model.

\section{Discussion}

The data shown here indicate that flow switching between Rutford Ice Stream and Carlson Inlet has not occurred for at least $3500 \mathrm{yr}$. If ice from the Rutford catchment had once flowed down Carlson Inlet and the flow in Carlson had then ceased and diverted into the Rutford main trough, then we would expect to see a remnant of stagnated ice which had the distinctive pattern of folding in the isochrones that is produced by convergent flow in the onset region, as exemplified by the structures on line J300 (Fig. 2a). This would be directly analogous to the situation on Kamb Ice Stream where the stagnated ice stream retains a fast-flow signature in the isochrones ( $\mathrm{Ng}$ and Conway, 2004).

The possibility remains, however, that such a flowswitching event occurred a long time ago and ice which once bore the signature of convergent flow has now advected over the grounding line. The present distance along Carlson Inlet between the downstream end of the radar data and the flow margin with Rutford Ice Stream is approximately $80 \mathrm{~km}$. The current flow rate of Carlson Inlet ice is between 7 and $35 \mathrm{~m} \mathrm{a}^{-1}$, so let us consider a long-term rate of $20 \mathrm{~m} \mathrm{a}^{-1}$ for 

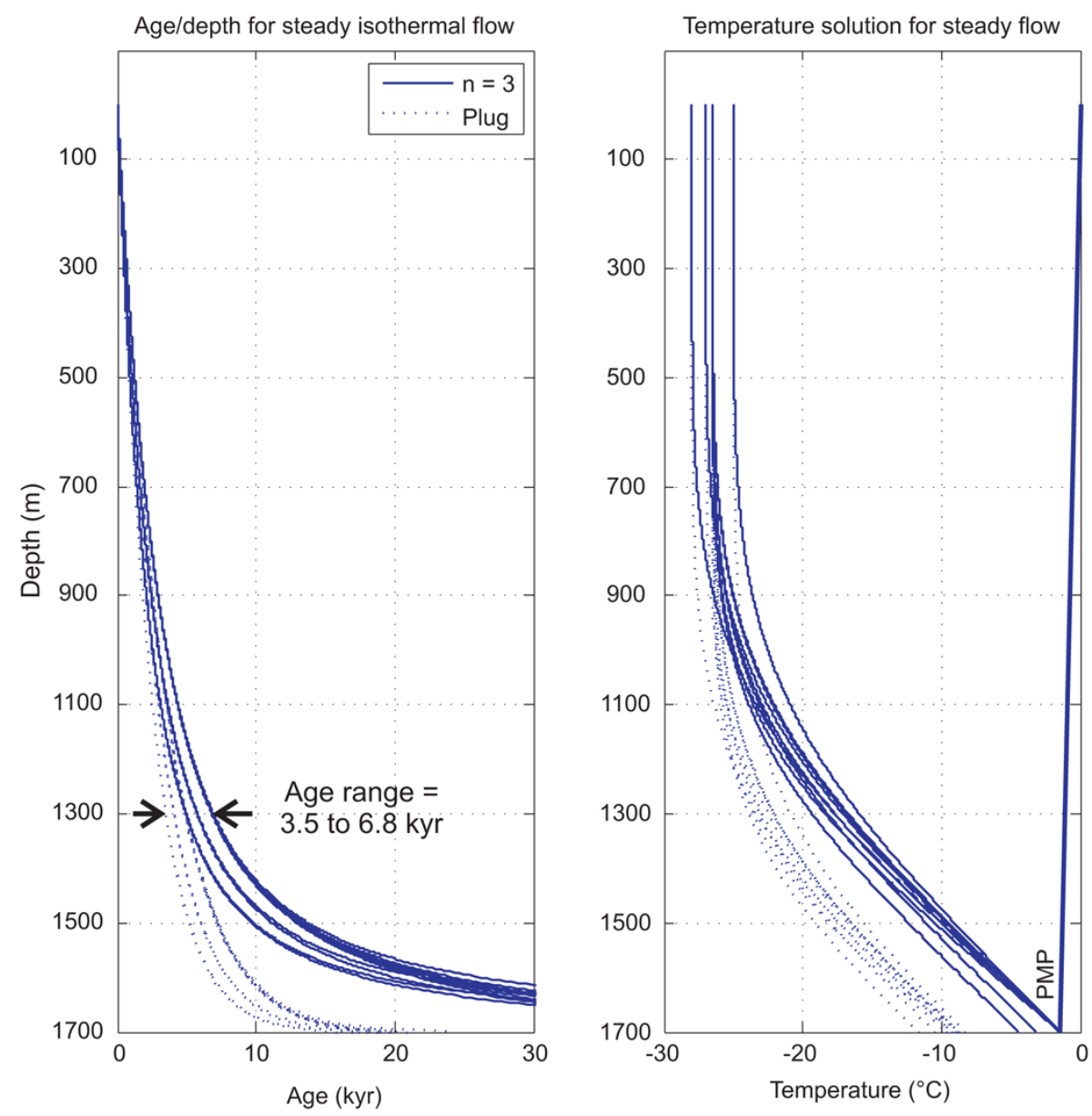

Fig. 5. Age-depth curves computed from a one-dimensional thermo-mechanical model (Hindmarsh, 1999) for line J501. The suites of curves were computed by varying the accumulation rate, geothermal heat flux and surface temperature across ranges expected for the area. The modelled ages for the deepest continuous radar reflector on line J501 fall in the range 3.5 to $6.8 \mathrm{kyr}$.

the sake of rough calculation. At such a rate, all ice which may have entered Carlson Inlet from the Rutford catchment would have been advected through the radar grid and replaced by local accumulation in a period of roughly $4000 \mathrm{yr}$. Clearly, the surface elevation profile and hence driving stress and flow velocity could have evolved over time and the calculation just presented is simplistic, however it serves to support the interpretation that there has not been flow switching between Rutford and Carlson in the past several thousand years.

Rutford Ice Stream and Carlson Inlet do have some common morphological features (Vaughan et al., 2008) but they do not share similar ice-flow histories during the past few thousand years. I now consider alternative explanations for the common morphologies. The width of Carlson Inlet and Rutford Ice Stream are similar and the margins are linear, however these characteristics may be due to geological control rather than glaciology. Aerogeophysical investigations showed that both Carlson Inlet and Rutford Ice Stream are located in graben flanked by deep crustal faults, thus the width and linearity are mostly controlled by Cenozoic extensional tectonics rather than glacial action (Garrett et al., 1987). Vaughan et al. (2008) also point out similarities in the basal morphology beneath Carlson Inlet and Rutford Ice Stream, noting that both have central ridges with flanking troughs. The radargrams presented here suggest an explanation for flanking troughs in Carlson Inlet. Ice flows off Fletcher Promontory and Kealey Ice Rise into Carlson Inlet, driven by relatively steep surface slopes (see, for example, the surface elevation profile in Vaughan et al., 2008, Fig. 4), sufficiently steep in places (such as adjacent to Line 145) to form a heavily crevassed ice fall. I speculate that this inflow causes compression in the margins resulting in shortwavelength folds (Figs. $2 \mathrm{~b}$ and 3). Thus there is clear evidence of lateral in-flow and compression towards the centre of Carlson Inlet in the ice column in the $10 \mathrm{~km}$ adjacent to the margin (Fig. 3). I speculate that the motion of ice away from the margin may transport sub-glacial sediments in the same direction. If the Carlson trough is a fault-bounded graben, then the material in the fault zones may be fault-shattered 
and more easily erodible. Thus enhanced erosion close to the margin and a means to transport the eroded sediments away from the margin may be sufficient to explain the troughridge-trough configuration of the Carlson bed profile. Similar arguments can be applied to Rutford Ice Stream where inflow from Fletcher Promontory on one side and large mountain glaciers flowing out of the Ellsworth Mountains on the other side may be contributing to enhanced erosion in the margins. Finally, this analysis only deals with a maximum time period of about $6800 \mathrm{yr}$. It may be that at some point prior to that time there was fast flow in Carlson Inlet which produced a large-scale bed morphology similar to that beneath Rutford Ice Stream before the present ice dynamics were established.

The subtle distinctions in the wavelength and amplitude of isochrone folding evident in the data from Talutis Ice Stream (Fig. 4a) are thought to be the result of differences in the degree of lateral compression affecting the upstream flow path. Valuable insights into flow history may be gained by the acquisition of similarly detailed 3-D grids of radar lines in areas such as the Siple Coast ice streams where changes in flow paths have been more common than the present study area.

\section{Conclusions}

The radar data provide no supporting evidence that Carlson Inlet is a relict ice stream. I conclude from an analysis of radar stratigraphy that the majority of Carlson Inlet has been near stagnant for at least between 3500 and $6800 \mathrm{yr}$. Over the same period, Rutford Ice Stream has been flowing rapidly, thus flow switching or partitioning between the two has not taken place during this time. This hypothesis may be further tested using numerical ice-flow modelling of the region which should be able to predict the distribution of zones of convergent flow under an evolving ice sheet surface during Holocene deglaciation. The flanks of Carlson Inlet have been subject to compressive in-flow from the adjacent ice rises. A number of the features common to both Carlson Inlet and Rutford Ice Stream may be due to underlying geological similarities rather than a common recent (3500-6800 yr) history of fast ice flow. These data constrain modelling of the historical development of this sector of the West Antarctic Ice Sheet and demonstrate that the acquisition of internal isochrone stratigraphy is vital to interpretation of flow history.

Acknowledgements. My thanks to D. Routledge for field support and to J. MacGregor and G. Leysinger-Vieli for constructive reviews.

Edited by: J. L. Bamber

\section{References}

Barrett, B. E., Nicholls, K. W., Murray, T., Smith, A. M., and Vaughan, D. G.: Rapid recent warming on Rutford Ice Stream, West Antarctica, from borehole thermometry, Geophys. Res. Lett., 36, L02708, doi:10.1029/2008GL036369, 2009.

Bougamont, M., Tulaczyk, S., and Joughin, I.: Response of subglacial sediments to basal freeze-on - 2. Application in numerical modeling of the recent stoppage of Ice Stream C, West Antarctica, J. Geophys. Res., 108, 2223, doi:10.1029/2002jb001936, 2003.

Catania, G. A., Conway, H., Raymond, C. F., and Scambos, T. A.: Evidence for floatation or near floatation in the mouth of Kamb Ice Stream, West Antarctica, prior to stagnation, J. Geophys. Res., 111, F01005, doi:10.1029/2005jf000355, 2006.

Christoffersen, P. and Tulaczyk, S.: Response of subglacial sediments to basal freeze-on - 1 . Theory and comparison to observations from beneath the West Antarctic Ice Sheet, J. Geophys. Res.-Sol. Ea., 108, 2222, doi:10.1029/2002jb001935, 2003.

Doake, C. S. M., Frolich, R. M., Mantripp, D. R., Smith, A. M., and Vaughan, D. G.: Glaciological Studies on Rutford Ice Stream, Antarctica, J. Geophys. Res., 92, 8951-8960, 1987.

Frolich, R. M., Vaughan, D. G., and Doake, C. S. M.: Flow of Rutford Ice Stream and comparison with Carlson Inlet, Antarctica, Ann. Glaciol., 12, 51-56, 1989.

Gades, A. M.: Spatial and temporal variations of basal conditions beneath glaciers and ice sheets inferred from radio echo soundings, Ph.D. thesis, University of Washington, 1998.

Garrett, S. W., Herrod, L. D. B., and Mantripp, D. R.: Crustal structure of the area around Haag Nunataks, West Antarctica: New aeromagnetic and bedrock elevation data, in: Gondwana Six: Structure, tectonics and geophysics, edited by: McKenzie, G. D., American Geophysical Union, Washington, 109-115, 1987.

Haran, T., Bohlander, J., Scambos, T., and Fahnestock, M. (compilers): MODIS mosaic of Antarctica (MOA) image map, Boulder, CO, USA, National Snow and Ice Data Center, Digital media, 2005.

Hindmarsh, R. C. A.: On the numerical computation of temperature in an ice sheet, J. Glaciol., 45, 568-574, 1999.

Hulbe, C. L. and Fahnestock, M. A.: West Antarctic ice-stream discharge variability: mechanism, controls and pattern of grounding-line retreat, J. Glaciol., 50, 471-484, 2004.

Jacobel, R. W. and Welch, B. C.: A time marker at $17.5 \mathrm{kyr}$ BP detected throughout West Antarctica, Ann. Glaciol., 41, 47-51, 2005.

Jacobel, R. W., Gades, A. M., Gottschling, D. L., Hodge, S. M., and Wright, D. L.: Interpretation of Radar-Detected Internal Layer Folding in West Antarctic Ice Streams, J. Glaciol., 39, 528-537, 1993.

Joughin, I. and Bamber, J. L.: Thickening of the ice stream catchments feeding the Filchner-Ronne Ice Shelf, Antarctica, Geophys. Res. Lett., 32, L17503, doi:10.1029/2005gl023844, 2005.

King, E. C.: Flow dynamics of the Rutford Ice Stream ice-drainage basin, West Antarctica, from radar stratigraphy, Ann. Glaciol., 50, 42-48, 2009.

King, E. C., Hindmarsh, R., Corr, H., and Bingham, R. G.: DELORES Mark 1: Construction and operation of the British Antarctic Survey Deep Look Radio Echo Sounder, International Conference on Radioglaciology and its applications, Madrid, 2008. 
Leysinger Vieli, G. J.-M. C., Hindmarsh, R. C. A., and Siegert, M. J.: Three-dimensional flow influences on radar layer stratigraphy, Ann. Glaciol., 46, 22-28, 2007.

Martin, C., Gudmundsson, G. H., Pritchard, H. D., and Gagliardini, O.: On the effects of anisotropic rheology on ice flow, internal structure, and the age-depth relationship at ice divides, J. Geophys. Res., 114, F04001, doi:10.1029/2008jf001204, 2009.

$\mathrm{Ng}$, F. and Conway, H.: Fast-flow signature in the stagnated Kamb Ice Stream, West Antarctica, Geology, 32, 481-484, doi:10.1130/g20317.1, 2004.

Retzlaff, R. and Bentley, C. R.: Timing of Stagnation of Ice StreamC, West Antarctica, from Short-Pulse Radar Studies of Buried Surface Crevasses, J. Glaciol., 39, 553-561, 1993.

Robin, G. d. Q. and Millar, D. H. M.: Flow of ice sheets in the vicinity of subglacial peaks, Ann. Glaciol., 3, 290-294, 1982.

Shapiro, N. M. and Ritzwoller, M. H.: Inferring surface heat flux distributions guided by a global seismic model: particular application to Antarctica, Earth Planet. Sc. Lett., 223, 213-224, doi:10.1016/j.eps1.2004.04.011, 2004.

Siegert, M. J., Payne, A. J., and Joughin, I.: Spatial stability of Ice Stream D and its tributaries, West Antarctica, revealed by radioecho sounding and interferometry, Ann. Glaciol., 37, 377-382, 2003.
Smith, A. M.: Basal conditions on Rutford Ice Stream and Carlson Inlet: implications for ice stream flow, in: Filchner Ronne Ice Shelf Programme, 13, Alfred Wegener Institute for Polar and Marine Research, Bremerhaven, 72-77, 2000.

Tulaczyk, S., Kamb, W. B., and Engelhardt, H. F.: Basal mechanics of Ice Stream B, West Antarctica 2. Undrained plastic bed model, J. Geophys. Res., 105, 483-494, 2000a.

Tulaczyk, S., Kamb, W. B., and Engelhardt, H. F.: Basal mechanics of Ice Stream B, West Antarctica 1. Till mechanics, J. Geophys. Res., 105, 463-481, 2000b.

Vaughan, D. G., Smith, A. M., Nath, P. C., and Le Meur, E.: Acoustic impedance and basal shear stress beneath four Antarctic ice streams, Ann. Glaciol., 36, 225-232, 2003.

Vaughan, D. G., Corr, H., Smith, A. M., Pritchard, H. D., and Shepherd, A. P.: Flow-switching and water piracy between Rutford Ice Stream and Carlson Inlet, West Antarctica., J. Glaciol., 54, 41-48, 2008.

Welch, B. C. and Jacobel, R. W.: Analysis of deep-penetrating radar surveys of West Antarctica, US-ITASE 2001, Geophys. Res. Lett., 30, 1444, doi:10.1029/2003GL017210, 2003. 